\title{
CDNA Expression
}

National Cancer Institute

\section{Source}

National Cancer Institute. cDNA Expression. NCI Thesaurus. Code C18687.

An analysis of all of the complementary DNA molecules expressed in a biological sample. 